\title{
Basic research gets bipartisan treatment
}

[WASHINGTON] A bipartisan group of US senators has set up a Science and Technology Caucus which, they promise, will work to build political support for basic research and for partnerships between government and industry.

The centrist group has been founded by Joseph Lieberman (Democrat, Connecticut) and Bill Frist (Republican, Tennessee). Frist, a heart surgeon by profession, is the new chairman of two Senate subcommittees which between them oversee most nonmilitary research and development carried out by the government.

The first meeting of the caucus, two weeks ago, brought a dozen prominent research administrators and industrialists to talk to senators about the government's role in 'fostering' technology. It was co-hosted by Frist, Lieberman, Pete Domenici (Republican, New Mexico) and Jay Rockefeller (Democrat, West Virginia).

Frist says the meeting was a great success. "The important thing is that all the senators stayed for the whole three hours," he says; this "says a lot about the importance they attach to the issue". According to Frist, the caucus is likely to be expanded, with the rest of the 100 senators invited to join. "We want to focus on the long-term role of the federal government in research and development," he says.

Speakers at the caucus included Paul Horn, research vice-president of IBM, and Robert Martin, chief technical officer of Lucent Technologies, as well as officials in the Clinton administration. Horn and Martin gave strong backing to the role of government in supporting technology programmes and basic research.

In contrast, Raymond Gilmartin, chairman of Merck, supported a clear division of

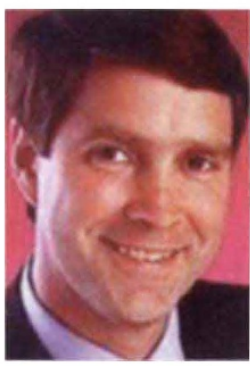

Frist: support at the heart of Congress. first practising physician to enter the Senate since 1928. As director of the heart and lung transplant programme at Vanderbilt University in Nashville, Tennessee, he published more than a hundred research articles, and wrote a book, Transplant, on the social and ethical implications of organ transplants.

The 45-year-old senator was named last month as chair of the science, technology and space subcommittee of the Senate commerce committee, which oversees the space agency NASA and the National Science Foundation. He also took the chair of the newly created public health and safety subcommittee of the Senate labor committee, which has jurisdiction over the National Institutes of Health (NIH) and the Food and Drug Administration. Together with his place on the powerful budget committee, these posts indicate that Frist will emerge as a pivotal figure in US research policy.

"There is huge support among senators for continued and further investment in research and development," says Frist. He says he would like the NIH to get increased funding of "about 5 per cent" this year, against the 2.6 per cent proposed by President Bill Clinton.

The formation of the caucus is seen in Washington as further evidence that the government is edging back towards bipartisan support for science and technology, after two years of bitter arguments, especially over technology policy. Republicans in the Senate have recently voiced strong support for science and technology spending, and the Congress is unlikely to seek cuts in the Clinton administration's proposed budget for science and technology.

Colin Macilwain

\section{Budget 'windfall' may tempt Canadian researchers back home}

[OTTAWA] The Canadian government plans to use money made unexpectedly available as a result of its tight fiscal policy to set up a foundation to improve research facilities, hoping this will help to attract back Canadian researchers working overseas.

The creation of a Canada Foundation for Innovation is one of the few new initiatives to be included in the federal budget announced in Ottawa last week. The foundation will receive about C $\$ 180$ million (US\$133 million) a year for five years from the government, and is intended to raise a slightly higher figure from private sources.

The money will be used to modernize the research infrastructure at universities and research hospitals in the areas of science, health, engineering and the environment. The foundation will be chaired by John Evans, formerly president of the University of Toronto, founding dean of McMaster University medical faculty, and director of the World Bank's population, health and nutrition department.

Evans, who is currently chairman and chief executive of Allelix, a biotechnology research company, says that many bright Canadians go abroad for postgraduate work and stay there, despite their wish to return, because of the lack of adequate facilities in Canada. The foundation will play an important role in encouraging them to "come back and perform at a very high level".

Plans for the foundation have been widely welcomed. Louis Siminovitch, director emeritus for research at Samuel Lunenfeld Research Institute, Mount Sinai Hospital, Toronto, calls it "an excellent idea", But he emphasizes that the foundation needs to address the problem of operating funds for the laboratories. "We'll have equipment and infrastructure, but our capacity to use it will be severely limited," says Siminovitch.

The situation is certainly serious. The Council for Health Research in Canada, which before the budget lobbied the government heavily for an overall 10 per cent increase in research funds, points out that funding for university research has declined by 14 per cent over two years. Taking inflation into account, the drop is even greater, at 25 per cent. Between 1994 and 1996, funds for the three federal grants councils dropped from C\$830 million to $\mathbf{C} \$ 782$ million.

Paul Martin, the Liberal government's finance minister, has been applying policies that include strenuous deficit-cutting measures. These have brought the national deficit to less than C $\$ 19$ billion, its lowest for many years. As this is more than C $\$ 5$ billion below his target, Martin is left with a windfall, about a quarter of which will go to the new foundation.

The innovation foundation will be an independent corporation, at arm's length from government. A board selected from the private sector, researchers and academics will provide grants to institutions to develop computer networks and databases, to buy equipment or to build research centres.

Those applying for the grants must agree to raise 60 per cent of the total they require from the private sector or from provincial governments. The federal government estimates this will bring up to C $\$ 2$ billion into the scheme.

The government has also announced that the Canadian Networks of Centres of Excellence will be made permanent, with an annual commitment of $\mathrm{C} \$ 47.4$ million.

The National Research Council's Industrial Research Assistance Program, which provides advice from experienced scientists to small and medium-sized enterprises, will be maintained at C\$96.5 million a year.

DavidSpurgeon 